\title{
Science starts early: A literature review examining the influence of early childhood teachers' perceptions of gender on teaching practices
}

\author{
Erin E. Hamel ${ }^{1}$
}

\begin{abstract}
Women are underrepresented in science fields as compared to men and although much research has been dedicated to understanding this disparity, most has been conducted on older aged children. However, this excludes the youngest and arguably most impressionable group of students: preschoolers. This study reviewed the literature to investigate how early childhood teachers' perceptions of gender influence their teaching practices. Qualitative analysis and coding of 31 articles resulted in five main categories: Teacher Perception, Curriculum, Teacher Interactions, Gender Identity, and Social Standing. Results are discussed in the context of early childhood science teaching practices to better understand the role of the teacher and gender bias in young children's preschool science experiences and how it may impact their future science interests.
\end{abstract}

\section{Article History}

Received: 30 July 2021

Accepted: 09 November 2021

\section{Keywords}

Early childhood; Science;

Preschool; Gender

\section{Introduction}

It is widely known that girls and women are underrepresented in science fields. One explanation for the noted discrepancy are gender socialization processes and societal attitudes that encourage traditional gender roles (Eccles et al., 1993; Eccles, 2007; Haworth et al., 2009; Leibham et al., 2013). Gender roles are believed to be socially constructed through values and beliefs present in relationships, society, and institutions (Davies, 2003). Gender roles are acquired early in life and have the potential to influence both males and females (Bigler \& Liben, 2006).

Developmental Intergroup Theory (Bigler \& Liben, 2006) aims to explain children's acquisition of stereotype and prejudice by proposing that "biases may be largely under environmental control and thus might be shaped via educational, social, and legal policies" (p.162). This idea is supported by a study of interactions in the home environment, finding that mothers' perceptions of their child's math abilities predicted child beliefs about their math ability (Gunderson et al., 2012). The family context has been a focus of research in developing gender roles. A study analyzing the conversations of parents and children during science-related tasks indicated that parents perceived science activities as more difficult and less interesting for their daughters than their sons (Tenenbaum \& Leaper, 2003). As a result, interactions with daughters and sons differed, indicating that differential treatment in regards to science occurs in the home environment. Further, research indicates that opportunities for science learning also varies, with parents of young boys ages 4 to 7 years old reporting more science-related opportunities for their child than parents of young girls of the same age (Alexander et al., 2012). Yet these differences are not confined to the home environment. In a study of interactions between parents and their children at a museum exhibit, researchers found that boys were three times more likely to receive science explanations from their parents than girls despite equal amounts of conversation (Crowley et al., 2001).

Likewise, it is conceivable that early childhood teachers, knowingly or unknowingly, exhibit similar gender bias in their interactions which may impact the children in their care. Teachers are largely in control of the quality of the classroom. This is particularly noteworthy because for young children, preschool is the 
first experience in a formal educational setting and sets the stage for development, future interests, and learning. Therefore, it is important to understand early childhood teacher's attitudes and perceptions of gender and how it may influence teacher practices. Teachers may explicitly or implicitly demonstrate gender biased views or stereotypes that influence their interactions, management, and pedagogical decisions in the classroom. Exposing young children to early gender stereotypes has been shown to influence children's long-term interests and ideas about intelligence (Bian et al., 2017). The present study systematically examines the literature using the research question, How do early childhood teachers perceive gender and how does this influence their teaching practices?

\section{Developmental Intergroup Theory}

This research is guided by Bigler \& Liben's (2006) Developmental Intergroup Theory (DIT), an approach to understanding and explaining how children develop stereotyping and prejudice. Other theories have attempted to explain children's acquisition of biases, DIT furthers those understandings by describing why some traits and not others become the focus of bias (Bigler \& Liben, 2006, 2007). Many variations of human dimensions exist, such as handedness, skin color, gender, and eye color; yet not all of these features are prominent factors in stereotyping and prejudice. DIT addresses this difference by combining concepts from social identity intergroup theory and cognitive theories of constructivism offered by Piaget to propose that stereotypes and prejudice are attained largely through explicit and implicit biases displayed in the environment coupled with children's developing ability for categorizing salient attributes (Bigler \& Liben, 2007). DIT suggests that three main processes occur for individuals when forming social stereotyping (Bigler \& Liben, 2007). First, the child establishes psychological salience of attributes that differ across people. Next, children categorize individuals by salient traits which is part of a cognitivedevelopmental process, constructivism, in which the child attaches meanings (positive or negative, true or untrue) to the categories they have created. Finally, this results in the third process of developing stereotypes and prejudice related to salient features. Given that the purpose of this paper is to explore children's preschool experiences related to adult perceptions of gender, the first process of DIT is particularly relevant. Understanding how children are establishing psychological salience of personal attributes, which is largely based on their experiences, may provide insights on how to prevent the formation of social stereotypes and prejudice. Bigler \& Liben (2007) suggest children's formation of psychological salience of attributes occurs in four ways: proportional group size, perceptual discriminability, explicit labeling and use, and implicit use. Proportional group size is relevant when working with populations that form a minority. In the case of this study, it is less important and was not a focus of my analysis as males and females make up roughly equal amounts of the population. For this study, the factors of perceptual discrimination, explicit use, and implicit use are most relevant.

\section{Perceptual Discrimination}

It is important to consider how children might be receiving messages from their environment and interactions and then subsequently shaping these messages into thoughts about their own or others gender. Perceptual discrimination refers to noticeable features, which young children tend to focus on, such as noticing hair color instead of less-noticeable handedness. Early childhood educators who intentionally draw attention to gender defining features, clothing, or traits would make gender more salient for children. While categorization is an important skill for children to learn and an almost infinite amount of ways exist for categorizing, some are more prevalent than others, such as gender. A continuous emphasis on gender categorization by a teacher may signal to children that this is an important bases for classifying people. This is significant in relation to science because children are forming ideas about their own gender and others gender which may unintentionally serve as a foundation for science-related stereotypes regarding who does and does not do science and who belongs in scientific fields. Beyond science, this raises ethical concerns for gender nonconforming children who would benefit from gender neutral language and deserve a supportive environment that respects their most authentic self. Gender nonconformity is beyond the scope of this paper, but warrants further research and consideration. 


\section{Explicit Labeling and Use}

Early childhood educators may explicitly categorize gender through their daily routines and practices (playing a song during music and movement that requires girls to move in one way and boys to move in another). Educators can explicitly enforce gender roles by managing the classroom with a focus on traditional gender behavior, such as intentionally leading girls to more feminine centers in the classroom to practice gender roles such as "playing house" or "cooking." This type of explict labeling and use could draw children's attention to and reinforce stereotypes that deter children from playing outside of their perceived gender role, potentially limiting girls' play and exploration of science-focused centers.

\section{Implicit Labeling and Use}

Implicitly shaping gender stereotypes in the early childhood classrooms occurs when educators make gender unnecessarily salient (instructing a child to "Ask the man if the mail has arrived"). Another aspect would be grouping children by gender without explicitly labeling the groups but then segregating the groups. This approach shows that when groups are segregated by a feature, although the feature is not labeled, higher bias occurs (Bigler \& Liben, 2007). Teachers implicit labeling has the potential to introduce or reinforce bias making it vital that teachers are aware of their own prejudice and biases related to children's gender and science.

Overall, DIT helps explain factors that may be contributing to the formation of social stereotypes and prejudice in young children. Early childhood teachers' perceptions of gender may influence their classroom teaching practices which could impact children's science learning opportunities and subsequently children's science-related interests and experiences. Thus, it is important to understand early childhood teachers' perceptions and attitudes about gender and how it influences their practices.

\section{Literature Review}

A generous amount of effort has been dedicated to studying gender inequality in science, technology, engineering, and mathematical (STEM) fields, most conducted at the middle-school, highschool, and college levels (Riegle-Crumb et al., 2012; Robinson-Cimpian et al., 2014; Wang, 2013). Even extensive reviews of the literature on girls and science are comprised largely of studies on older students, with only a handful of articles on elementary schools identified (Brotman \& Moore, 2008). Unfortunately, this overlooks the youngest and arguably most impressionable population of students: preschoolers.

Findings on science achievement are at odds. In elementary school, girls show less interest in science than boys with girls' interest continuing to decline with age so that by ages 10-14 a marked difference in science attitudes by gender appears (Catsambis, 1995). Unfortunately, not only does interest wane for girls, but they perceive science as uninteresting and boring (Jones et al., 2000). Although some research indicates girls have a less positive attitude and interest in science, there is evidence that they perform equally as well or better than their male counterparts in science class (Catsambis, 1995; Greenfield, 1996; Jones et al., 2000). However, more recent literature reveals a gender gap in science achievement beginning as early as first grade (Curran \& Kellogg, 2016) and persisting over time, resulting in a call for intervention at an earlier stage of development, such as preschool (Morgan et al., 2016). One area of consensus between early childhood and the science field is on the suitability of teaching science in the early years. Most agree that children have a natural curiosity of the world around them which motivates them to explore scientific concepts and topics in authentic ways. In addition, research supports science education beginning early on in life as a way to develop positive attitudes towards science, expose children to scientific concepts through language and teachable moments, and develop scientific thinking (Eshach \& Fried, 2005; Morgan et al., 2016). There is increasing evidence that children's early interests (including those that are science-related) can persist over time and influence the course of learning (Alexander et al., 2012) underscoring the importance of providing early opportunities for exploring science.

The early childhood environment may be ripe for children's science exploration but barriers exist to teaching science. Teachers report lack of confidence and content knowledge (Gerde et al., 2018; Kallery \& Psillos, 2001; Park et al., 2017), time (Greenfield et al., 2009; Park et al., 2017), and materials (Tu, 2006) as 
factors impeding science instruction in the classroom. Notably, these reasons impact both structural and process quality indicators. Structural indicators refer to a characteristic of the environment and process indicators refer to interaction between individuals (Cassidy et al., 2005). Structural and process indicators are concepts by which the quality of early childhood environments are often assessed. Barriers in both of these areas are likely to affect the amount and quality of science teaching and subsequently, children's science interest and learning. If the quality and quantity of science teaching in preschool is low for all children, it is especially detrimental for young girls who benefit when teachers foster their sustained science interest (Leibham et al., 2013). For preschool-aged girls, an intense science interest predicts a significantly higher science self-concept at 8 years old (Leibham et al., 2013). Science self-concept is defined as "an understanding of their attributes, abilities, and values" (Leibham et al., 2013) and can be constructed through daily interactions such as play (Chafel, 2003). For preschool-aged boys, early interests are not predictive of science achievement as they are for girls (Leibham et al., 2013). This underlines the importance of fostering girls' early interests in science during the preschool years.

An important component of early childhood education is the foundational relationships upon which subsequent experiences and knowledge are built. Research implicates teacher attitude as a contributing influence on developing gender stereotypes in children (Beilock et al., 2010; Robinson-Cimpian et al., 2014). Whether implicit or explicit, teachers' actions and words can convey gender bias and influence the types of activities and interests' young children develop, even shaping later career choices (Bian et al., 2017). Gender bias has the potential to negatively and inaccurately influence young children's image of themselves and their capabilities.

In summary, gender differences in preschool science experiences and science achievement are less understood than those that occur at other levels of education. Reported differences in science achievement could mean two things: girls are either as capable as boys in science but do not select science careers, or that girls' lack of interest and/or achievement is identifiable early on and persists. Either way, this warrants further investigation of classroom processes, such as teacher and child interactions in the preschool years, which have been identified as an ideal time for teaching and exploring science concepts. Science teaching is lacking, in part, because early childhood teachers feel unprepared to teach science activities (Greenfield et al., 2009). While children are naturally curious about the world around them, developing scientific reasoning skills requires both engagement and interaction around science content and materials (Gelman \& Brenneman, 2012; Morris et al., 2012). Science materials, a structural component of the early childhood environment, are selected and displayed for use by classroom teachers who lack confidence in their science abilities (Greenfield et al., 2009). Teachers identify several reasons that science instruction is lacking in early childhood such as their lack of confidence and instructional time but research to date has not included teacher perceptions of gender that may also impact their interactions with children in the classroom (Greenfield et al., 2009). These perceptions may implicitly or explicitly influence both structural and process quality in the early childhood environment. A clearer understanding of how teachers' gender perceptions may influence their teaching practices and subsequently impact children's learning opportunities and experiences in the preschool classroom is needed. The purpose of this paper is to address this gap in the literature.

\section{Method}

The goal of this paper is to examine research on early childhood teachers' perceptions of gender in the classroom. I used several search strategies to identify studies. First, a discovery catalog and database ProQuest Educational Resources Information Center (ERIC), were searched using two combinations of terms: 1) preschool teacher and gender; and 2) teacher attitude, gender, and preschool. This resulted in 37 articles and 31 articles, respectively. These terms were selected with a goal of including early childhood articles related to teacher perception and gender in any domain of learning. To identify articles related specifically to gender topics in education and science content in preschools, the search was narrowed to a selected set of journals (Brotman \& Moore, 2008). Seven specific journals were searched that focus on science in education: Journal of Research in Science Teaching, International Journal of Science Education, Journal of Science 
Science starts early: A literature review examining the influence of early childhood...

Teacher Education, Science Education, and Research in Science Education. A review of two other journals were also included because they are not limited to the field of science but might provide insights into the research topic: Gender and Education and American Education Research Journal (Brotman \& Moore, 2008). These efforts resulted in an additional 4 articles specific to gender at the early childhood level. Lastly, a search was conducted of PsychINFO using a combination of the terms early childhood education, teacher attitudes, teacher perceptions and gender. This resulted in an additional 32 articles. In total, 104 articles were originally identified.

After reviewing the collected articles, it was apparent that several of the articles were beyond the scope of this paper and did not meet the purpose of the study. In order to address the proposed research question in a systematic way, three main inclusion criteria were established for the review. First, the article must be published in a peer reviewed journal; this eliminated doctoral dissertations, master theses, and other articles printed in news-type magazines. Second, the article must be relevant to the topic of early childhood teachers' perceptions of gender and children 6 years old and younger. Third, the article must be in English. This led to research contributions from the following countries: Australia, Canada, Denmark, Finland, Indonesia, Israel, Japan, Norway, Poland, Qatar, Spain, Sweden, Turkey, and the United States. Specific interest included the teachers' practice influencing children, teacher perceptions of gender, and teacher values about gender for children kindergarten age and younger.

Articles that were excluded from the review were those that did not meet the purpose of the research. This included studies on efforts to increase the amount of male preschool teachers employed in the early childhood field, transgender and non-binary research and trainings for early childhood teachers, the development of sexuality in preschool, parent gender perceptions and influence, and articles reporting gender differences among various academic domains or interventions. After categorizing articles using established inclusion and exclusion criteria, 27 articles were identified for review. As recommended in methodological literature, a secondary search was conducted using references lists from recent literature reviews (Fraenkel et al., 2016). This resulted in an additional four articles that met inclusion criteria. A complete summary of the final 31 articles analyzed for this review is available in Table 2.

\section{Data Analysis}

A thorough review was conducted using content analysis (Saldaña, 2015) to systemmatically examine articles for purpose, participants and setting, methodology, and major findings. Major findings were manually coded by the reported overall effect on young children. Articles that were primarily focused on teacher attitudes towards gender but did not include child outcomes made up their own category. Three articles included a child outcome based on parent perception but not teacher perception. These were removed from the final analysis. Fourteen initial codes were then combined and reduced to five overall categories that signify the findings in the literature (Saldaña, 2015). Articles were organized into established categories demonstrating the range of results in each category. Another aspect of the articles analyzed included the date of publication of the studies to identify potential patterns or trends in how this topic has been explored both recently and historically. In the sections that follow I discuss the major findings and implications related to science learning in the early childhood classroom. It is noteworthy that the articles originate from multiple countries, adding complexity to the synthesis of findings, but strengthening the emphasis on the importance of the need to understand the impact of gender on children in early childhood classrooms world-wide.

\section{Results}

The five categories that emerged from data analysis were: Teacher Perception, Curriculum, Teacher Interactions, Gender Identity, and Social Standing. Each of these categories was created by combining the initial codes (See Table 1). 
Table 1. Categories and underlying codes

\begin{tabular}{lllll}
\hline Teacher Perception & Curriculum & Teacher Interactions & Social Standing & Gender Identity \\
\hline Teacher perception & Play & Behavior & Interactions with peers & Understanding of \\
Teacher attitude & Opportunities for play & Adult relationships & Social standing & identity \\
Awareness & Selection of activities & Engagement with & & \\
& Materials for play & teacher & & \\
& & Discipline & \\
\hline
\end{tabular}

Teachers' perceptions of gender were the focus of most of the research studies (see Figure 1) and established the category Teacher Perception. Teachers' perceptions of how they view young children by gender provides insight into teacher thoughts and opinions but it is not possible to infer how this translates into practice and pedagogical decisions without further evidence. Studies that reported child outcomes suggest that an early childhood teacher's perception of gender influences four areas, which generated the other remaining categories: Curriculum, Teacher Interactions, Social Standing, and Gender Identity (see Figure $1)$.

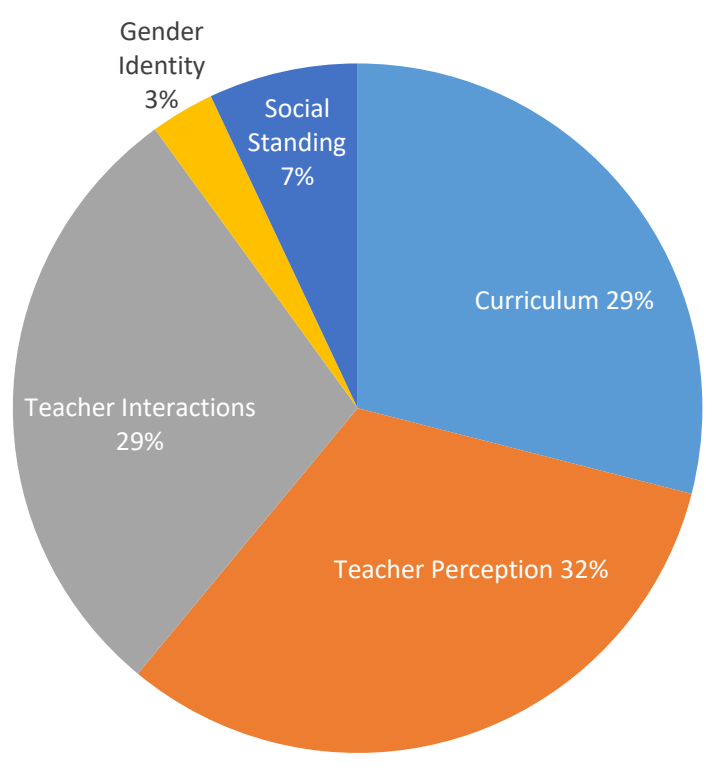

Figure 1. Proportion of Articles by Category

The oldest publication in the review was categorized in the Curriculum category; however, this category also contained recent publications as well. The Curriculum category includes articles related to children's learning, play, along with the materials and environment that create the curriculum. Young children's work is often considered their play and learning through play is a foundational element of early childhood education which has been studied for many years, so it is not surprising that this category contained the oldest publication. Results show that chronologically the category with the most recent publications was Teacher Interactions. This could in part be due to an emphasis in the field on process quality indicators and improved measures of teacher interactions.

\section{Teacher Perceptions of Gender}

Early childhood teachers' perceptions of gender were investigated through surveys, questionnaires, and semi-structured interviews (See Table 2). One of the articles in this category was a review of articles related to sexism in the context of early childhood. In that review conducted by Duke and McCarthy (2009), nine articles (39\%) identified that some teachers were uncomfortable with non-stereotypical gender behavior by children and eight $(26 \%)$ of the articles described ways that early childhood education 
Science starts early: A literature review examining the influence of early childhood...

programs reinforce traditional gender roles. In one study, teachers thought that gender stereotypes were reinforced through the use of children's literature and even television programming. Other articles included in this category shed light on teachers experiences, perceptions and classroom practices. For example, early childhood teachers recall playing in gender stereotypical ways in their own childhood (Sandberg \& Pramling-Samuelsson, 2005). Interestingly, Erden (2004) found that although teachers reported an egalitarian view on gender, when asked whether they agreed or not with gender traditional statements such as, "girls are more emotional than boys," up to $40 \%$ of teachers agreed. This indicates that teachers perceive the genders as having traditional differences while also reporting a belief in gender equality. In the classroom, teachers who held egalitarian attitudes had also adopted egalitarian discipline styles indicating that at least in one way teacher perception is related to teacher practice (Erden, 2004). How teachers perceive appropriateness of children's behavior, especially aggression, by child gender showed differences as well. For example, female teachers differed from male teachers in their identification and ratings of children's aggression (Pellegrini et al., 2011). Male teachers identified more aggression in the classroom than their female counterparts (Pellegrini et al, 2011). In addition, one study showed that male teachers thought that a child displaying aggressive behavior would perform better and be less likely to be excluded in play (Bosacki et al., 2015).

In summary, early childhood teacher's perceptions of children's gender is influenced by the teacher's own previous experiences and their own gender. Perceptions of gender can influence the meaning that teacher's assign to children's behavior and how they respond to behavior through discipline style. While this is informative, the extent to how these perceptions influence children in the classroom is less clear.

\section{Curriculum}

In the literature addressing curriculum, a variety of qualitative and quantitative methods measuring learning and play in the classroom were used (See Table 2). Researchers examined both structural and process quality to address children's classroom experiences. Structure quality was investigated by measuring aspects of the environment such as the types of books and toys available to children as well as where in the classroom the teacher most often played. Processes of play were measured through examining the types of activities and the interactions children had with teachers in the classroom, which were investigated using observations, interviews, and focus groups. One study in this category explored the environment and culture of the classroom. Borve and Borve (2017) studied the classroom physical environment and conducted interviews with teachers and assistant teachers ( 15 female and 3 male) at a Kindergarten in Norway. They found that the environment was primarily designed by the female teachers, leading to an environment described by the teachers as "feminine". Areas were designed based on how teachers felt children would use the space which led to teachers creating and designing the classroom in a traditionally gendered way. For example, teachers identified boys as playing in ways that were rougher and louder and consequently, required more space. Girls, on the other hand, were thought to play in more quiet and gentle ways. This resulted in areas designed for boys taking up more space than those designed for girls. And although children occasionally crossed into all spaces, teachers thought that children used the spaces differently based on child gender. Authors suggest that spaces were not designed and set up for gender neutral play and that the intention for play impacts how children used the space. This resulted in play practices that mimicked adults' ideas of gender (Borve \& Borve, 2017). Similarly, interviews with teachers during focus groups in Spain revealed gender division in areas of the classroom consistent with their views on how boys and girls play (Rodriguez et al., 2006). In these focus groups, teachers noted that they had expectations for girls' play that was mothering and nurturing and when boys played in this same caring way, some of the teachers even responded with surprise. It is important to note that while teachers voiced an expectation for gendered behavior, they did not negatively reinforce nonconforming play. In fact, they used moments of unexpected nonconforming play to talk about equity (Rodriguez et al., 2006).

Another structural component of the environment and important part of the curriculum is literature, including the books available within the classroom and those selected and read by the teacher. In a study of 618 book readings, 433 unique books were presented to children across six preschools in Sweden. Results 
showed that significantly fewer girls were main characters than boys (Lynch, 2016). Both teachers' and children's choices for books to read were significantly more likely to have a male main character. Gender equity in literature is deficient in preschool classrooms (Lynch, 2016). This is problematic because children may perceive girls as less important because they hold a lesser role in literature than boys. When children view less minorities, including females, in literature, they may internalize that they have less value in society (Lynch, 2016). It is important to note that teachers' selections of children's books are limited to books in publication and the lack of children's books with female main characters is largely out of their control.

Toy selection is another important aspect of play. One study conducted by Trawick-Smith and colleagues (2015) showed that teachers and parents select toys that engage boys more than girls. Researchers asked teachers and parents to nominate nine toys that they felt would benefit child development. Observations of the toys being used in the classroom indicated that child gender was an influencing factor in children's selection of toys and the quality with which it was played (Trawick-Smith et al., 2015). Results showed that when boys played with the toys, the quality play score was higher (Trawick-Smith et al., 2015). Quality was measured in seven areas: thinking and learning, problem solving, curiosity and inquiry behaviors, sustained interest, creative expression, symbolic representations, and interactions, communications, and collaborations with peers. This finding could be problematic because it indicates that teachers and parents may not select toys that can engage both genders in equally beneficial ways. Children selected items they enjoyed but their play with these toys didn't automatically result in high-quality play. Thus teachers may need to carefully consider how to enhance or scaffold play with a preferred toy. Teachers' careful observations of play should go beyond child preference and include a focus on quality of engagement.

Rodriguez and colleagues (2006) found that teachers gave children the freedom to select and engage in play without adult intervention and that it was not necessary to address gender stereotypes in the classroom because children are choosing their play preference. As mentioned earlier, teachers expected children to play in traditional gendered ways and therefore create an environment conducive to gendered play (Borve \& Borve, 2017). It is also plausible that children have been socialized to play in gendered ways via media, society, and other influences and that early childhood environments perpetuate the stereotype by not disputing them. Another study found that a teacher's presence in areas of the classroom, including the science area, drew children to the area to play (Tomes, 1995).

Early childhood teachers are also responsible for planning activities. Planning is influenced by how teachers view gender roles, as shown by interviews and observations in a study of teachers and children in Australia (Chapman, 2016). Using observations of the classroom and interviews with four teachers, researchers found that teachers who held more egalitarian views on child gender and play appeared to acknowledge gender issues in the classroom and implement strategies to counter gender roles or stereotypes (Chapman, 2016). The idea that teachers perceive play differently based on child gender is not new and was supported in a study by Logue and Harvey (2010) where teachers shared their belief that boys participate in more superhero play and girls participate in more nurturing activities, such as "playing house" or "family". Teachers then self-reported stopping dramatic play almost half the time (48\%) for boys and only $29 \%$ of the time for girls, and intervening in social conflict more frequently for boys than for girls. The same teachers thought that their own plans for dramatic play were more productive than children's own imaginative play (Logue \& Harvey, 2010). Taken together, these findings suggest that teachers' perceptions of gender play can influence how teachers plan for play and may result in differences in how children engage in and are supported in their play.

Outside of planned activities, teachers have the opportunity to use everyday experiences as teachable moments. Granger and colleagues (2017) observed children's free play and found that teachers facilitated gender-typed activities based on the gender make-up of the group. For example, 27 female teachers in Head Start classrooms working with girls facilitated masculine and gender-neutral activities significantly more often than feminine activities. This same study found that gender-neutral activities were implemented more frequently with groups of girls than with groups composed of boys (Granger et al., 2017). 


\section{Teacher Interactions with Children}

Early childhood teachers have countless interactions with children each day. Most research in this category indicates that a child's gender influences the interactions he or she has with the teacher (see Table 2). Interactions include classroom conversations, responses, directives, and engagement between the teacher and the child. For example, in-service and pre-service preschool teachers in Sweden thought "headstrong" and "disobedient" behavior from girls was less allowable than similar behaviors from boys (Hedlin \& Aberg, 2018). This led to the teacher interacting in a dismissive way towards the student who was then labeled as "very troublesome" (Hedlin \& Aberg, 2018). Another study showed a comparable finding when staff members at 80 kindergartens in Demark responded to gender-related dilemmas. Teachers' responses to the gender dilemmas differed by child gender, but not by teacher gender, indicating that regardless of teacher gender, teachers consistently treated boys and girls differently (Olsen \& Smeplass, 2016). A similar outcome was found in a study in Indonesia, where informal and formal interviews with teachers, conversations with children, and field notes of daily classroom activities were analyzed to explore care from staff. Results indicated that teachers cared for children in stereotypical ways that likely preserved gendered behavior in children (Adriany \& Warin, 2014). For example, in the annual school musical celebrating diversity and uniqueness, the female children were assigned feminine roles of flowers, fairies, and a princess; while the male children took on the role of fish. The message of respecting differences and celebrating each individual was lost in the expectation for children to perform traditional gender roles. Overall, teachers reported that cultural diversity was celebrated at the Indonesian school; however, gender was not openly addressed and traditional gender behavior was encouraged (Adriany \& Warin, 2014). In a study conducted in the United States, differential treatment in four teaching practices (physical interactions between children, verbal and physical directions of body, voice control, and behavior management) contributed to gender differences in 5-year-old children in 5 preschool classrooms (Martin, 1998). Differences included how the teacher interacted with a child through restricting a child's voice, dressing-up, limiting physicality, or instructing children how to physically be with one another (Martin, 1998). Still, some hope for gender equitable interactions in preschool classrooms exists. In a large study of 342 children aged $34-63$ months from 100 classrooms in the United States, children's positive engagement with their teachers was analyzed for associations with individual child factors (age and gender). Researchers found that neither age nor gender were significantly associated with children's positive engagement with their teachers (Vitiello et al., 2012). Notable differences from this study as compared to the older Martin (1998) study include the number of participants, the extended child age range, and the measure of engagement. In the latter study, a standardized observational assessment, the InCLASS, was used to measure interactions; whereas the former used a semi-structured observation with field notes. In summary, support exists to suggest early childhood teachers' interactions with young children are influenced in some ways by child gender.

\section{Social Standing}

The Social Standing category was created by combining studies indicating that a child's perceived popularity, relationships, or social competence was influenced by adult gender perceptions. Only two articles belong to this category (See Table 2). The purpose of the first study was to explore the impact of gender stereotyping on young children. Researchers found that teachers rated girls and boys who conformed to gender stereotypes as more likable than their non-conforming peers (Sullivan et al., 2018). In fact, teachers rated girls more likable than boys and boys were likely to experience criticism for violating gender stereotypes (Sullivan et al., 2018). One aim of the second study was to assess and compare gender differences in prosocial behavior among preschoolers in a Middle Eastern country. While gender differences in prosocial behavior are well documented, this research was unique in that it was the first in Doha, Qatar (Al-Thani \& Semmar, 2017). Teachers were asked to complete a questionnaire regarding their interactions with students and observations. Findings indicated that teachers perceived boys as displaying less prosocial behaviors than girls. Significant gender differences were found in subscales of teacher preferred behavior, peer preferred behavior, and school adjustment indicating that teachers of preschool children in Doha, Qatar, rated boys as underperforming girls in social competence (Al-Thani \& Semmar, 
2017).

\section{Child Gender Identity}

The category of Gender Identity contained only one study, which was conducted in Japan (See Table 2). Gender identity is viewed as an individual's perception of who they are and how they characterize themselves in terms of culturally defined male and female roles (Wood \& Eagly, 2015). For example, a study of private day care teachers in Tokyo was conducted over the course of one year, in which researchers observed one to two times per month for how children and teachers used the word kawaii (cute, lovable). Teachers used kawaii as an indication of gender and described girls using this term which led to girls using kawaii to describe or refer to themselves (Burdelski \& Mitsuhashi, 2010). This research found that female, but not male, children adopted kawaii as part of their identity. 
Table 2. Articles by category

\begin{tabular}{|c|c|c|c|c|}
\hline Author(s) (Year) & Purpose of Study & Participants and Setting & Method & Major Findings \\
\hline \multicolumn{5}{|l|}{ Curriculum } \\
\hline Borve, H.E. \& Borve, E. (2017) & $\begin{array}{l}\text { Explore teacher perception of the } \\
\text { impact of the physical } \\
\text { environment on the culture of play } \\
\text { in the classroom }\end{array}$ & $\begin{array}{l}\text { Private kindergarten in } \\
\text { Norway consisting of } 73 \\
\text { children and } 18 \text { lead and } \\
\text { assistant teachers }\end{array}$ & $\begin{array}{l}\text { Case study using recorded } \\
\text { staff interviews }\end{array}$ & $\begin{array}{l}\text { Teachers arranged the environment with expectations } \\
\text { and intentions of learning in mind that often led to } \\
\text { gender influenced design. }\end{array}$ \\
\hline Chapman, R. (2016) & $\begin{array}{l}\text { Explore how gender roles might } \\
\text { be displayed or supported without } \\
\text { the teacher being aware }\end{array}$ & $\begin{array}{l}2 \text { preschool teachers, } 2 \\
\text { assistant teachers, } 39 \\
\text { children ages } 4-5 \text { years old } \\
\text { from Australia }\end{array}$ & $\begin{array}{l}\text { Interviews with teachers } \\
\text { and observations of } \\
\text { children }\end{array}$ & $\begin{array}{l}\text { Teachers' planning of activities is influenced by how } \\
\text { they viewed play and gender roles. }\end{array}$ \\
\hline $\begin{array}{l}\text { Rodriguez, MdC., Pena, J.V., } \\
\text { Fernandez, C.M., \& Vinuela, M.P. } \\
\text { (2006) }\end{array}$ & $\begin{array}{l}\text { Investigate gender discourse used } \\
\text { by nursery school teachers }\end{array}$ & $\begin{array}{l}35 \text { teachers of children } \\
\text { aged 3-6 years old in Spain }\end{array}$ & $\begin{array}{l}\text { Semi-structured } \\
\text { interviews of } 7 \text { focus } \\
\text { groups }\end{array}$ & $\begin{array}{l}\text { Teachers reported a gender division in areas of the } \\
\text { classroom where children play that is consistent with } \\
\text { their expectations that children play in traditional } \\
\text { gender defined ways. }\end{array}$ \\
\hline $\begin{array}{l}\text { Granger, K., Hanish, L., } \\
\text { Kornienko, O. \& Bradley, R.H. } \\
\text { (2017) }\end{array}$ & $\begin{array}{l}\text { Explore the frequency that } \\
\text { teachers facilitated gender } \\
\text { conforming and gender-neutral } \\
\text { activities during free play }\end{array}$ & $\begin{array}{l}37 \text { female teachers in Head } \\
\text { Start classrooms }\end{array}$ & $\begin{array}{l}\text { Observation of teacher- } \\
\text { student interactions and } \\
\text { group composition during } \\
\text { free play }\end{array}$ & $\begin{array}{l}\text { Teachers facilitated gender-typed activities based on the } \\
\text { gender make-up of the group. Teachers facilitated } \\
\text { gender-neutral activities with all girls groups more } \\
\text { frequently than with all boys groups. }\end{array}$ \\
\hline Logue, M.E., \& Harvey, H. (2010) & $\begin{array}{l}\text { Understand preschool teacher's } \\
\text { views and practices on pretend } \\
\text { play }\end{array}$ & $\begin{array}{l}98 \text { teachers of } 4 \text {-year-old } \\
\text { children }\end{array}$ & Mailed questionnaires & $\begin{array}{l}\text { Teachers reported significant differences in play for boys } \\
\text { and girls. Teachers intervened in social conflict among } \\
\text { boys more often than girls. }\end{array}$ \\
\hline Lynch, M. (2015) & $\begin{array}{l}\text { Explore how teachers discuss } \\
\text { gender in social media }\end{array}$ & $\begin{array}{l}7 \text { Online message boards } \\
7 \text { Kindergarten teachers }\end{array}$ & $\begin{array}{l}\text { Netnography of data } \\
\text { collected from social } \\
\text { media and semi- } \\
\text { structured interviews. }\end{array}$ & $\begin{array}{l}\text { The most prevalent theme, "Dramatic play is for girls." } \\
\text { Results of interviews indicated that teachers' views of } \\
\text { gendered play are projected onto their students. }\end{array}$ \\
\hline Lynch, L. (2016) & $\begin{array}{l}\text { Analyze the content of teacher } \\
\text { selected children's literature in } \\
\text { preschools in Sweden }\end{array}$ & $\begin{array}{l}618 \text { book readings of } 433 \\
\text { unique books across } 6 \\
\text { preschools in Sweden to } \\
\text { children aged 3-6 years }\end{array}$ & $\begin{array}{l}\text { Teachers recorded the } \\
\text { books read during group } \\
\text { story times over a period } \\
\text { of six months }\end{array}$ & $\begin{array}{l}\text { Significantly less girls were main characters than boys. } \\
\text { Teachers' and children's choice of books to read was } \\
\text { significantly more likely to include a male main } \\
\text { character than a female. }\end{array}$ \\
\hline Sniegulska, M., \& Pisula, W. (2013) & $\begin{array}{l}\text { Analyze children's free play with a } \\
\text { new toy }\end{array}$ & $\begin{array}{l}189 \text { preschool children } \\
\text { aged 3-7 years old from } \\
\text { private and public } \\
\text { kindergartens in Poland }\end{array}$ & $\begin{array}{l}\text { Video recorded, 15-minute } \\
\text { observation of child with a } \\
\text { new toy }\end{array}$ & No gender differences were found in exploration of toys. \\
\hline Tomes, R. (1995) & $\begin{array}{l}\text { Explore teacher influence on } \\
\text { children's selection of activities } \\
\text { and areas }\end{array}$ & $\begin{array}{l}58 \text { children aged } 3-5 \text { years } \\
\text { old and their teachers }\end{array}$ & $\begin{array}{l}\text { Observations during free } \\
\text { play once a week for } 6 \\
\text { weeks. }\end{array}$ & $\begin{array}{l}\text { Students were drawn to areas of art, block, library and } \\
\text { science if the teacher was present. Boys preferred large } \\
\text { blocks and girls preferred to play in the art area. }\end{array}$ \\
\hline
\end{tabular}


Erin E. HAMEL

\begin{tabular}{|c|c|c|c|c|}
\hline $\begin{array}{l}\text { Bosacki, S., Woods, H., \& Coplan, } \\
\text { R. (2015) }\end{array}$ & $\begin{array}{l}\text { Explore early childhood teacher's } \\
\text { perceptions of rough and tumble } \\
\text { play based on the gender of the } \\
\text { child }\end{array}$ & $\begin{array}{l}22 \text { teachers of young } \\
\text { children in Canada }\end{array}$ & $\begin{array}{l}\text { Online survey collecting } \\
\text { demographics and beliefs } \\
\text { and attitudes related to } \\
\text { hypothetical play } \\
\text { scenarios }\end{array}$ & $\begin{array}{l}\text { Physical play is perceived differently by male and } \\
\text { female teachers. Male teachers reported that boys who } \\
\text { were more physically aggressive in their play would } \\
\text { perform better academically and would be less likely to } \\
\text { be excluded. Female teachers held the opposite belief. }\end{array}$ \\
\hline $\begin{array}{l}\text { Dewar, B., Servos, J., Bosacki, S., \& } \\
\text { Coplan, R. (2013) }\end{array}$ & $\begin{array}{l}\text { Explore early childhood teacher } \\
\text { perceptions of how gender } \\
\text { impacts the classroom. }\end{array}$ & $\begin{array}{l}41 \text { teachers throughout } \\
\text { Canada }\end{array}$ & $\begin{array}{l}\text { Semi-structured telephone } \\
\text { interviews }\end{array}$ & $\begin{array}{l}\text { Themes of professional development, critical self- } \\
\text { awareness, and critical thinking emerged. Teachers saw } \\
\text { reflection as a way to become aware of their own biases } \\
\text { and promote more inclusive gender roles. }\end{array}$ \\
\hline $\begin{array}{l}\text { Duke, T.S. \& McCarthy, K.W. } \\
\text { (2009) }\end{array}$ & $\begin{array}{l}\text { Literature review of sexuality and } \\
\text { sexism in the context of early } \\
\text { childhood education }\end{array}$ & $\begin{array}{l}31 \text { articles published } \\
\text { between 1975-2007 }\end{array}$ & $\begin{array}{l}\text { Coding system based on } \\
\text { publication type, research } \\
\text { design, and emergent } \\
\text { themes }\end{array}$ & $\begin{array}{l}\text { Eight articles described ways that programs in early } \\
\text { childhood and elementary school reinforce gender roles } \\
\text { and the oppression of women noting children's } \\
\text { literature and television programming as a source for } \\
\text { stereotypes. }\end{array}$ \\
\hline Erden, F. (2004) & $\begin{array}{l}\text { Explore early childhood teachers' } \\
\text { attitudes toward gender roles and } \\
\text { discipline }\end{array}$ & $\begin{array}{l}130 \text { female public school } \\
\text { teachers of kindergarten } \\
\text { and first grade }\end{array}$ & $\begin{array}{l}\text { Attitudes Toward Gender } \\
\text { Roles Scale (AGRS) and } \\
\text { Attitudes Toward } \\
\text { Discipline Scale (ADS) }\end{array}$ & $\begin{array}{l}\text { Up to } 40 \% \text { of teachers agreed with gender traditional } \\
\text { statements and researchers found a statistically } \\
\text { significant relationship between teachers' attitudes } \\
\text { towards discipline and their attitudes towards gender } \\
\text { roles. }\end{array}$ \\
\hline Hyland, N. (2010) & $\begin{array}{l}\text { Review of research on developing } \\
\text { practices that address equity in the } \\
\text { classroom }\end{array}$ & $\begin{array}{l}\text { Review of two } \\
\text { approaches: culturally } \\
\text { relevant teaching and } \\
\text { critical pedagogy to develop } \\
\text { equity }\end{array}$ & $\begin{array}{l}\text { Describe research showing } \\
\text { how two pedagogies have } \\
\text { been use in early } \\
\text { childhood classrooms to } \\
\text { address race, gender, and } \\
\text { sexual orientation }\end{array}$ & $\begin{array}{l}\text { Research identifies ways to reconstruct gender } \\
\text { stereotyped messages, which can be detrimental to both } \\
\text { boys' and girls' development. Teachers role is to address } \\
\text { power imbalances across race and gender through } \\
\text { empowering underrepresented children. }\end{array}$ \\
\hline Hyvonen, P. (2008) & $\begin{array}{l}\text { Explore teachers' perceptions of } \\
\text { mixed-gender play activities }\end{array}$ & $\begin{array}{l}14 \text { preschool and primary } \\
\text { teachers in Finland }\end{array}$ & Teacher interviews & $\begin{array}{l}\text { Teachers noted a goal of education should be to } \\
\text { overcome gender boundaries. Teachers intentionally do } \\
\text { not separate gender in their classrooms and they } \\
\text { question gendered behavior and ask children to reflect } \\
\text { on it. }\end{array}$ \\
\hline Lundeberg, M.A. (1997) & $\begin{array}{l}\text { Investigate how preservice } \\
\text { teachers' perceptions of gender } \\
\text { compare with teacher and student } \\
\text { interactions }\end{array}$ & 48 preservice teachers & $\begin{array}{l}\text { Analyze data on } \\
\text { participates in a } \\
\text { discussion of gender bias } \\
\text { in classrooms }\end{array}$ & $\begin{array}{l}\text { Majority ( } 71 \%) \text { of preservice teachers thought that } \\
\text { classroom discussion was equal. More males } \\
\text { contributed comments in class discussion. Preservice } \\
\text { teachers reflected on the importance of creating equal } \\
\text { experiences for both genders. }\end{array}$ \\
\hline Pellegrini et al. (2011) & $\begin{array}{l}\text { Explore the differences in } \\
\text { observations and ratings of } \\
\text { preschool children's aggression }\end{array}$ & $\begin{array}{l}89 \text { preschool children } \\
5 \text { five teachers }\end{array}$ & $\begin{array}{l}\text { Daily observations of } \\
\text { children } \\
\text { Teacher checklist to } \\
\text { measure child aggression }\end{array}$ & $\begin{array}{l}\text { Trained female researchers rated children's aggression } \\
\text { the same as female teachers who had not been trained. } \\
\text { Trained male researchers recorded more aggression } \\
\text { compared to females. }\end{array}$ \\
\hline $\begin{array}{l}\text { Sandberg, A., \& Pramling- } \\
\text { Samuelsson, I. (2005) }\end{array}$ & $\begin{array}{l}\text { Investigate the different ways } \\
\text { male and female preschool }\end{array}$ & $\begin{array}{l}20 \text { preschool teachers in } \\
\text { private and public }\end{array}$ & $\begin{array}{l}\text { In-person, semi-structured } \\
\text { interviews }\end{array}$ & $\begin{array}{l}\text { Preschool teachers reflected their play as children was } \\
\text { gender stereotyped. Female teachers had no play }\end{array}$ \\
\hline
\end{tabular}


Science starts early: A literature review examining the influence of early childhood...

teachers think of play preschools in Sweden

Four classrooms of 60 Four classrooms of 60

Examine the effects of toys on play, including factors that enhance learning and development old. Parents and teachers nominated 9 toys for the research project. willingness and avoided playing with children as they thought they would disturb the play. Male teachers were more playful.

Trawick-Smith, T., Wolff, J., Koschel, M., \& Vallarelli, J. (2015)

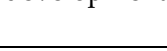

\section{Teacher Interactions}

\begin{tabular}{lll}
\hline Teacher Interactions & \\
Adriany, V. \& Warin, J. (2014) & $\begin{array}{l}\text { Explore the relationship between } \\
\text { care and gender in an early } \\
\text { childhood environment }\end{array}$ & $\begin{array}{l}4 \text { teachers, 1 principal, the } \\
\text { school owner, and 28 } \\
\text { children between 2 and } 6 \\
\text { years old in Indonesia }\end{array}$ \\
\hline
\end{tabular}

Benozio, A. \& Diesendruck, G. Assess how children are (2017)

\section{Assess how children are}

Observations of toy use recorded using hidden cameras and microphones. when boys were engaged with them, suggesting that Toy quality was assessed parents and teachers need to identify toys that can using a play quality with engage boys and girls in equally beneficial ways.
Teachers care for children in stereotypical ways that likely perpetuate gendered behavior in children. While most differences were celebrated at the school, gender was not outwardly addressed.

Children age three to four years old distribute items based on being fair or equal, regardless of teacher's preference. Children aged five to six, distributed items based on teacher preference and matched gender of
Bigler, R. S. (1995)

Explore how the use of gender categorization in the classroom attributes to gender stereotyping in behaving toward others

111 children aged 3-6 years from 5 kindergartens in Israel

Ethnographic research interviews with adults, child conversation, and artifacts

Teachers randomly assigned to demonstrate a preference and child behavior assessed on their response related to teacher's preference

Classroom teachers

randomly assigned to exhibit three

categorization styes: gender, color group, and control group. Semi-structured

Researchers investigate the conditions of stereotypes in teacher training and their influence on children in the classroom

children ages 6-11 three classrooms

10 female and 10 male preschool teachers in Sweden

7 teachers working with nterviews lasting 30-60 minutes.

Ethnographic observations and interviews with preservice teachers.

preservice teachers using field notes, recipients. Teacher interactions may impact how children respond.

Children in a classroom where the teacher used gender as a categorization method increased their gender stereotyping. Children in these classrooms were more likely to categorize occupations as appropriate for male or females along traditional gender stereotypes.

Qualitative semi-

5 preschool classrooms

Investigate the development of the gendered child in preschool

serving 5 -year-old

and field notes of

classrooms
Researchers identify that teachers and staff found girls demonstrating headstrong and disobedient behavior as less permissible than boys demonstrating similar behaviors. Girls acting this way were dismissed and perceived as "very troublesome."

Martin, K. (1998)

Researchers report and reflect on 
Erin E. HAMEL

gendered attitudes of kindergarten staff members members at 80

Kindergartens from 2

Danish municipalities

\begin{tabular}{l} 
Owens, S., Smothers, B.C., \& Love, \\
F.E. (2003) \\
\hline $\begin{array}{l}\text { Şahin-Sak, İ. T., Sak, R., \& Tezel- } \\
\text { Şahin, F. (2018) }\end{array}$
\end{tabular}

Vitiello, V.E., Booren, L.M.,

Downer, J.T., \& Williford, A.P.

(2012)

Examine gender bias in schools

related to access of education and

Systematic review of

gender inequalities

literature

Investigate the perceptions of

preschool teachers related to

behavior management

Investigate the source of

variability in child engagement

between child factors and

classroom settings

Social Standing

Assess prosocial behaviors of

preschool children and differences

in teacher perceptions of gender from 10 schools in Doha,

Qata

310 preschool teachers in

Turkey

342 preschool aged

children (34-63 months)

from 100 classrooms in 40

urban schools

84 female teachers

pedagogical dilemmas, 2

specific to gender

regardless of the teacher's own gender. Staff, regardless

of gender, treated boys and girls differently.

Three areas of focus:

history of women and

education, schools

encouragement of gende

inequality, and solutions

for equity in schools

Questionnaire

Classroom observation of

activity settings and

inCLASS observationa

system

Gender bias or sexism in the classroom is subtle and often unconscious. Differences in how boys and girls are treated results in a learned pattern of how to behave early on in life.

Female preschool teachers were more likely to use techniques for behavior management involving listening, relationship building, and comforting children.

Child gender was not significantly associated with children's negative or positive engagement with their teachers.

Teachers completed the Prosocial Behaviors of

Children-Teachers'

Teachers perceived that boys displayed less prosocial behaviors than their female peers. Significant

differences in gender occurred in teacher preferred

behavior, peer preferred behavior, and school

Perceptions instrument adjustment.

Study 1: Online task to rate typical or desirable characteristics for 3 year old by gender

Sullivan, J., Moss-Racusin, C.,

Explore the impact of gender

Study 1: 635 adults

Lopez, M., \& Williams, K. (2018) stereotyping on young children

Study 2: 697 adults

All recruited from Amazon

Mechanical Turk.

Study 2: Online task of

gender conforming and

non-conforming vignettes

of preschool application

Study 1: Researchers developed a list of traits for each gender.

Study 2: Stereotype conforming boys and girls were more likeable than their non-conforming peers. Girls overall were more likeable than boys.

\section{Gender Identity}

Burdelski, M. \& Mitsuhashi, K. (2010)
Explore how teachers and children use the word kawaii (cute,

oveable) and how it impacts social interactions in the classroom
Private day care classroom with 14 children and their female teachers in Japan
Recorded observations o the classroom taken 1-2

imes a month over one year
Children learn the meaning of kawaii through social interactions. Teachers use kawaii as an indication of gender. Teachers assessed girls using the term. Female children used kawaii more when referring to themselves and female peers. 
Science starts early: A literature review examining the influence of early childhood...

\section{Conclusion and Discussion}

Several notable ideas emerged from this review of early childhood literature related to gender. First, teachers' perceptions of gender are influenced by their own gender and prior experiences (Borve \& Borve, 2017; Bosacki et al., 2015; Pellegrini et al., 2011; Sandberg \& Pramling-Samuelsson, 2005). Second, to some degree interactions in the classroom contain bias and stereotypes and implicit gender bias may be present in how activities are designed and what materials are selected for use in the classroom (Borve \& Borve, 2017; Rodriguez et al., 2006; Trawick-Smith et al., 2015). Third, children receive gendered messages from early childhood teachers which may impact their own view of themselves (Adriany \& Warin, 2014; Burelski \& Mitsuhashi, 2010; Granger et al., 2017; Olsen \& Smeplass, 2016). Next, these ideas are interpreted while considering implications for science teaching and learning in the early years.

When applying a lens of science learning to findings in the Curriculum category, it is important to remember that an intense early interest in science for girls is related to a higher self-concept in science later in childhood (Leibham et al., 2013). Young girls may self-select play that is more nurturing in nature but the teacher's planning could also be contributing to traditional gender play in the classroom. Early childhood teachers are influential in fostering science interest through their presence and planning of activities that increase opportunities for science play for children (Leibham et al., 2013; Tomes, 1995). Research shows that early childhood teachers do not feel confident teaching science and that they would prefer to play with children in other areas of the classroom instead (Gerde et al., 2018; Kallary \& Psillos, 2001). As a consequence, the science area of the classroom may not be selected for play as often and science content may be addressed less frequently than other content areas which could be especially detrimental to igniting and fostering young girls' early interests in science. Further, not all early childhood programs are equally focused on science. Nature-based preschool programs have a special focus on environmental education and spend large amounts of time in the outdoors. Such programs may provide more frequent opportunities for science learning yet little is known about the role of gender in such experiences. It is possible that nature provides an optimal backdrop for equal science learning for both genders. Children enrolled at nature preschools may accrue less gender bias and gendered beliefs about themselves and their science abilities when immersed in a natural outdoor learning environment as compared to a traditional early childhood setting that contains gendered play areas and gendered toys. More research on environment and curriculum is needed to answer these questions.

In early childhood education, research shows that interactions between children and teachers have an important role in predicting child outcomes (Early et al., 2007). The results from this review indicate that teachers interact differently with children based on their gender (Granger et al., 2017; Olsen \& Smeplass, 2016). The impact of differential treatment on science learning is still largely unknown and represents a gap in the literature for future researchers to investigate. Interactions during science activities and exploration in the early childhood classroom could be a key element to understanding later differences in science achievement and interest between boys and girls. And although the focus of the review is constrained to perceptions of early childhood teachers, it is worth noting how interactions with other authority figures, such as parents, could be contributing to the divide. In a study of interactions between parents and their children at a science museum, parents used more explanatory conversations with their sons than with their daughters (Crowley et al., 2001). In fact, conversations with sons were three times more likely to include explanations and this held true at all ages (1-8 years) even though children who heard explanations had rarely asked questions (Crowley et al., 2001). It is not a far leap to suggest that similar differences in interactions could be happening in early childhood classrooms given the research presented in the Teacher Interactions category showing that child gender impacts teacher's responses and teaching practices (Adriany \& Warin, 2014; Martin, 1998; Olsen \& Smeplass, 2016). Fortunately, a recent study found that of 755 questions asked during preschool science lessons, no significant differences were found regarding gender of the child recipient (Hamel et al., 2021). Further, Granger and colleagues (2017) found that gender-neutral activities were implemented more frequently with groups of girls than boys. While it is promising that teachers are engaging with young girls in gender-neutral activities, it stops short 
of crossing into more stereotypically masculine activities, which are often associated with science. Providing stereotypically masculine activities to all genders is an opportunity to counter stereotypical gender activities by providing a variety of experiences to all children regardless of gender.

Findings from the social standing category are relevant to the topic of gender and science because girls (and boys, for that matter) may be more inclined to conform to gender stereotypes to achieve approval or be liked. Masculinity is often linked to traits of objectivity, lack of emotion, and rationality, which frequently are associated with the subject of science (Brotman \& Moore, 2008). Exhibiting feminine nurturing behaviors such as building relationships, creativity, and showing emotion can be viewed as incompatible to science (Brotman \& Moore, 2008). Unfortunately, these associations may lead children to conform for the sake of acceptance or contradict gender stereotypes with the risk of being rejected. Of course, it is important to note that real differences may exist in social behaviors of boys and girls. Some researchers have found that relational aggression is more common in girls in early childhood and boys show more physical aggression than girls, although not significantly (Ostrov et al., 2004). While difference between social behaviors may exist, teachers should encourage all students to engage in science activities and content. Attempts have been made to contradict associations of masculinity and science including a program coined "Creative Expression in Science" (Meyer, 1998) aimed at elementary science teachers. Early childhood teachers could also benefit from professional development and training that emphasizes acceptance and encouragement of all students to engage in science topics.

Lastly, language is powerful and has the ability to influence how children view themselves. The use of the Japanese word kawaii is an example of explicit labeling that impacts how children identify themselves by gender (Burdelski \& Mitsuhashi, 2010). Explicit labeling is an important facet of DIT which provides an explanation of core processes responsible for contributing to young children's understandings of bias and stereotype, including gender. DIT posits that four factors may influence the formation of gender bias or stereotypes in young children, one of which is explicit labeling and use (Bigler \& Liben, 2006). If children, especially young girls, are forming (mis)understandings of themselves and their science abilities during preschool, it is important to understand not only where and from whom these messages originate (parents, teachers, and society), but how children receive and internalize them as part of their identity.

These findings also have implications for early childhood teacher preparation programs who can apply and share the results within required coursework on gender equity and science pedagogy. Early childhood teachers' awareness and understandings of their own biases and perceptions can help them to reflect on their pedagogical choices and the subsequent impact on children's learning opportunities in the classroom. Policymakers and administrators should also consider offering professional development for early childhood teachers on promoting gender equity by eliminating gender bias and stereotypes as a way to enhance teacher practices. It should be emphasized here that this review included research conducted in international settings which requires special consideration of socio-cultural influences of gender development. Therefore, the cultural norms and context of each unique early care program should be thoughtfully considered.

\section{Limitations}

This review explored how teacher perceptions related to gender influenced teachers' practices. Limitations of the review include the small number of articles collected. Although efforts were made to encompass all relevant articles in the early childhood literature, it is possible that some studies were missed. A wider search to include other areas of male-dominated domains and careers, such as math, might also provide additional insights but was beyond the scope of this review. In addition, the body of literature analyzed relied heavily on self-report measures such as questionnaires, surveys, and semi-structured interviews of teachers to identify their perceptions and gender bias. For these types of measures, social desirability may play a role in how teachers reported their perceptions of gender and lead to answers that were not true depictions of actual perceptions. One form of bias termed implicit bias, is based on the notion that unconscious beliefs or processes can impact our actions. For teachers, this is particularly important because implicit biases may affect teachers' "understanding, actions, and decisions in an unconscious 
Science starts early: A literature review examining the influence of early childhood...

manner" (Staats, 2016). A well-intentioned teacher may unconsciously interpret a situation or behavior in a way that is biased therefore observations of children and teachers during science activities may provide a different perspective.

\section{Future Directions}

The results of this review highlight future avenues for research. First, it would be useful to use measures that can reveal implicit gender bias. The desire to respond in a more socially acceptable manner may play a role in how teachers report their perceptions and feelings about gender. A second direction for future research would be an increase in observational data collection to observe teacher and child behavior in natural classroom settings. Only one-third (34\%) of the articles in the review included classroom observations, with others focusing instead on surveys and interviews. Additionally, preschool aged children are capable of answering questions related to their perceptions, interests, and experiences and could provide insight into preschool science activities.

Looking forward, it is also important to recognize that separately, the fields of science and early childhood education have made valuable contributions to understanding this topic. Gender gaps in science fields and occupations are widely acknowledged and continue to be investigated. At the same time, early childhood researchers are dedicated to understanding the teaching and learning of science in early childhood (Silby \& Watts, 2017). However, exploring science teaching and learning in early childhood specifically for gender bias or differential treatment by gender is lacking. Expanding the field to include more investigations at the early childhood level could provide a more complete understanding of the issue of gender inequality in science fields prior to formal schooling. It also has the potential to provide valuable information about the teacher's role in counteracting or contributing to gender differences in science with an overarching goal of increasing the participation of women in the science field. Further investigation into this topic may prove mutually beneficial for both the fields of science and early childhood education. An area of importance for further research is examining how gender bias in the classroom impacts all children, including gender-nonconforming children. Early childhood classrooms should provide equitable science learning opportunities for all children.

\section{Declarations}

Competing interests: The authors declare that they have no competing interests

Funding: No funding was used for this study.

\section{References}

Adriany, V., \& Warin, J. (2014). Preschool teachers' approaches to care and gender differences within a child-centered pedagogy: Findings from an Indonesian kindergarten. International Journal of Early Years Education, 22(3), 315-328. https://doi.org/10.1080/09669760.2014.951601

Alexander, J. M., Johnson, K. E., \& Kelley, K. (2012). Longitudinal analysis of the relations between opportunities to learn about science and the development of interests related to science. Science Education, 96(5), 763-786. https://doi.org/10.1002/sce.21018

Al-Thani, T., \& Semmar, Y. (2017). An exploratory study of teachers' perceptions of prosocial behaviors in preschool children. International Journal of Educational Development, 53, 145-150. https://doi.org/10.1016/j.ijedudev.2017.01.005

Beilock, S.L. Gunderson, E.A., Ramirez, G., \& Levine, S.C. (2010). Female teachers' math anxiety affects girls' math achievement. Proceedings of the National Academy of Sciences, 107(5), 1860. https://doi.org/10.1073/pnas.0910967107

Benozio, A., \& Diesendruck, G. (2017). Parochial compliance: Young children's biased consideration of authorities' preferences regarding intergroup interactions. Child Development, 88(5), 1527-1535. https://doi.org/10.1111/cdev.12654

Bian L., Leslie, S., \& Cimpian, A. (2017). Gender stereotypes about intellectual ability emerge early and influence children's interests. Science, 335(6323), 389-391. https://doi.org/10.1126/scienceaah6524

Bigler, R.S. (1995). The role of classification skill in moderating environmental influences on children's gender stereotyping: A study of the functional use of gender in the classroom. Child Development, 66(4) 1072-1087. https://doi.org/10.1111/j.14678624.1995.tb00923.x

Bigler, R.S. \& Liben, L.S. (2006). A developmental intergroup theory of social stereotypes and prejudice. Advances in Child Development 
Erin E. HAMEL

and Behavior, 34, 38-89. https://doi.org/10.1016/S0065-2407(06)80004-2

Bigler, R.S. \& Liben, L.S. (2007). Developmental intergroup theory: Explaining and reducing children's social stereotyping and prejudice. Current Directions in Psychological Science, 16(3), 162-166. https://doi.org/10.1111/j.1467-8721.2007.00496.x

Borve, H.E., \& Borve, E. (2017). Rooms with gender: Physical environment and play culture in kindergarten. Early Child Development and Care, 187(5-6), 1069-1081. https://doi.org/10.1080/03004430.2016.1223072

Bosacki, S., Woods, H., \& Coplan, R. (2015). Canadian female and male early childhood educators' perceptions of child aggression and rough-and-tumble play. Early Child Development and Care, 185(7), 1334-1147. https://doi.org/10.1080/03004430.2014.980408

Brotman, J.S., \& Moore, F.M. (2008). Girls and science: A review of four themes in the science education literature. Journal of Research in Science Teaching, 45(9), 971-1002. https://doi.org/10.1002/tea20241

Burdelski, M., \& Mitsuhashi, K. (2010). "She thinks you're kawaii": Socializing affect, gender, and relationships in a Japanese preschool. Language in Society, 39(1), 65-93. https://doi.org/10.1017/S0047404509990650

Cassidy, D.J., Hestenes, L.L., Hansen, J.K., Hegde, A., Shim, J., \& Hestenes, S. (2005). Revisiting the two faces of child care quality: Structure and process. Early Education \& Development, 16(4), 505-520. https://doi.org/10.1207/s15566935eed1604 10

Catsambis, S. (1995). Gender, race, ethnicity, and science education in the middle grades. Journal of Research in Science Teaching, 32(3), 243-257. https://doi.org/10.1002/tea.3660320305

Chafel, J. (2003). Socially constructing concepts of self and other through play. International Journal of Early Years Education, 11(3), 213222. https://doi.org/10.1080/0966976032000147334

Chapman, R. (2016). A case study of gendered play in preschools: How early childhood educators' perceptions of gender influence children's play. Early Child Development and Care, 186(8), 1271-1284. https://doi.org/10.1080/0300430.2015.1089435

Crowley, K., Callanan, M., Tenenbaum, H.R. \& Allen, E. (2001). Parents explain more often to boys than to girls during shared scientific thinking. Psychological Science, 12(3), 258-261. https://doi.org/10.1111/1467-9280.00347

Curran, F. C. \& Kellogg, A. T. (2016). Understanding science achievement gaps by race/ethnicity and gender in kindergarten and first grade. Educational Researcher, 45(5), 273-282. https://doi.org/10.3102/0013189X16656611

Davies, B. (2003). Frogs and snails and feminist tales: Preschool children and gender. Hampton Press.

Dewar, B.A., Servos, J.E., Bosacki, S.L., \& Coplan, R. (2013). Early childhood educators' reflections on teaching practices: The role of gender and culture. Reflective Practice, 14(3), 381-391. https://doi.org/10.1080/14623943.2013.767234

Duke, T.S. \& McCarthy, K.W. (2009). Homophobia, sexism, and early childhood education: A review of the literature. Journal of Early Childhood Teacher Education, 30(4), 385-403. https://doi.org/10.1080/10901020903320320

Early, D.M., Maxwell, K.L., Burchinal, M., Alva, S., Bender, R.H., Bryant, D., Cai, K., Clifford, R.M., Ebanks, C., Griffin, J.A., Henry, G.T., Howes, C., Iriondo-Perez, J., Jeon, H.J., Mashburn, A.J., Peisner-Feinberg, E., Pianta, R.C., Vandergrift, N., \& Zill, N. (2007). Teachers' education, classroom quality, and young children's academic skills: Results from seven studies of preschool programs. Child Development, 78(2), 558-580. https://doi.org/10.1111/j.1467-8624.2007.01014.x

Eccles, J.S. (2007). Where are all the women? Gender differences in participation in physical science and engineering. In S.J. Ceci \& W.M.Williams (Eds.), Why aren't more women in science?: Top researchers debate the evidence (pp. 199-210). American Psychological Association.

Eccles, J.S., Arberton, A., Buchanan, C.M., Janis, J., Flanagan, C., Harold, R., ... Reuman, D. (1993). School and family effects on the ontogeny of children's interests, self-perceptions, and activity choices. In J. E. (Ed.), Nebraska Symposium on Motivation: Developmental perspectives on motivation (145-208). University of Nebraska Press.

Erden, F. (2004). Early childhood teachers' attitudes toward gender roles and towards discipline. Hacettepe University Journal of Education, 27, 83-90.

Eshach, H., \& Fried, M.N. (2005). Should science be taught in early childhood? Journal of Science Education and Technology, 14(3), 315336. https://doi.org/10.1007/s10956-005-7198-9

Frankel, J.R., Wallen, N.E., \& Hyum, H.H. (2016). How to design and evaluate research in education. McGraw-Hill.

Gelman, R., \& Brenneman, K. (2012). Moving young "scientists-in-waiting" onto science learning pathways: Focus on observation. In J. Shrager \& S. Carver (Eds.), The journey from child to scientist: Integrating cognitive development and the education sciences (pp. 155-169). American Psychological Association. https://doi.org/10.1037/13617-008

Gerde, H. K., Pierce, S. J., Kyungsook, L., \& Van Egeren, L. A. (2018). Early childhood educators' self-efficacy in science, math, and literacy instruction and science practice in the classroom. Early Education and Development, 29(1), 70-90. https://doi.org/10.1080/10409289.2017.1360127

Granger, K., Hanish, L., Kornienko, O., \& Bradley, R. (2017). Preschool teachers' facilitation of gender-typed and gender-neutral activities during free play. Sex Roles, 76(7-8), 498-510. https://doi.org/10.1007/s11199-016-0675-1 
Science starts early: A literature review examining the influence of early childhood...

Greenfield, T.A. (1996) Gender, ethnicity, science achievement, and attitudes. Journal of Research in Science Teaching, 33(8), 901-933.

Greenfield, D.B., Jirout, J., Dominguez, X., Greenberg, A., Maier, M., \& Fuccillo, J. (2009). Science in the preschool classroom: A classroom programmatic research agenda to improve science readiness. Early Education and Development, 20(2), 238-264. https://doi.org/10.1080/10409280802595441

Gunderson, E., Ramirez, G., Levine, S., \& Beilock, S. (2012). The role of parents and teachers in the development of gender-related math attitudes. Sex Roles, 66(3), 153-166. https://doi.org/10.1007/s11199-011-9996-2

Hamel, E., Joo, Y., Hong, S. Y., \& Burton, A. (2021). Teacher questioning practices in early childhood science activities. Early Childhood Education Journal, 49(3), 375-384. https://doi.org/10.1007/s10643-020-01075-z

Haworth, C.M.A., Dale, P.S., \& Plomin, R. (2009). Sex differences and science: the etiology of science excellence. Journal of Child Psychology and Psychiatry, and Allied Disciplines, 50(9), 1113-1120. https://doi.org/10.1111/j.1469-7610.2009.02087.x

Hedlin, M., \& Aberg, M. (2018). Fussy girls and chattering women - the construct and subordination of femininity in preschool teacher training. Early Child Development and Care, 188(2), 220-230. https://doi.org/10.1080/03004430.2016.1211120

Hyland, N.E. (2010). Social justice in early childhood classrooms: What the research tells us. Young Children, 65(1), 82-87.

Hyvonen, P. (2008) Teachers' perceptions of boys' and girls' shared activities in the school context: Towards a theory of collaborative play. Teachers \& Teaching, 14(5/6), 391-409. https://doi.org/10.1080/13540600802571312

Jones, M.G., Howe, A., \& Rua, M. J. (2000). Gender differences in students' experiences, interests, and attitudes toward science and scientists. Science Education, 84(2), 180-192. https://doi.org/10.1002/(SICI)1098-237X(200003)84:2<180::AID-SCE3>3.0.CO;2-X

Kallery, M., \& Psillos, D. (2001). Pre-school teachers' content knowledge in science: Their understanding of elementary science concepts and of issues raised by children's. International Journal of Early Years Education, 9(3), 165-179. https://doi.org/10.1080/09669760120086929

Leibham, M.B., Alexander, J.M. \& Johnson, K.E. (2013). Science interests in preschool boys and girls: Relations to later self-concept and science achievement. Science Education, 97(4), 574-593. https://doi.org/10.1002/sce.21066

Logue, M.E., \& Harvey, H. (2010). Preschool teachers' views of active play. Journal of Research in Childhood Education, 24(1), 32-49. https://doi.org/10.1080/02568540903439375

Lundeberg, M.A. (1997). You guys are overreacting: Teaching prospective teachers about subtle gender bias. Journal of Teacher Education, 48(1), 55-61.

Lynch, L. (2015). Guys and dolls: A qualitative study of teachers' view of gendered play in kindergarten. Early Child Development and Care, 185(5), 679-693. https://doi.org/10.1080/03004430.2014.950260

Lynch, L. (2016). Where are all the pippis?: The under-representation of female main and title characters in children's literature in the Swedish preschool. Sex Roles, 75(9-10), 422-433. https://doi.org/10.1007/s11199-016-0637-7

Martin, K.A. (1998). Becoming a gendered body: Practices of preschools. American Sociological Review, 63(4), $494-511$. https://doi.org/10.2307/2657264

Meyer, K. (1998). Reflections on being female in school science. Toward a praxis of teaching science. Journal of Research in Science Teaching, 35(4), 463-471. https://doi.org/10.1002/(SICI)1098-2736(199804)35:4<463::AID-TEA16>3.0.CO;2-A

Morgan, P.L., Farkas, G., Hillemeier, M.M., \& Maczuga, S. (2016). Science achievement gaps begin very early, persist, and are largely explained by modifiable factors. Educational Researcher, 45(1), 18-35. https://doi.org/10.3102/0013189X16633182

Morris, B. J., Croker, S., Masnick, A., \& Zimmerman, C. (2012). The emergence of scientific reasoning. In H. Kloos, B. Morris, \& J. Amaral (Eds.), Current Topics in Children's Learning and Cognition (pp. 61-82). Intech Open. https://doi.org/10.5772/53885

Olsen, B., \& Smeplass, E. (2016). Gender and distribution of educational values among the staff in kindergartens. Early Child Development \& Care, 188(8), 1202-1218. https://doi.org/10.1080/03004430.2016.1261125

Ostrov, J.M., Woods, K.E., Jansen, E.A., Casas, J.F., \& Crick, N.R. (2004). An observational study of delivered and received aggression, gender, and social-psychological adjustment in preschool: "This white crayon doesn't work...". Early Childhood Research Quarterly, 19(2), 335-371. https://doi.org/10.1016/j.ecresq.2004.04.009

Owens, S.L., Smothers, B.C., \& Love, F.E. (2003). Are girls victims of gender bias in our nation's schools? Journal of Instructional Psychology, 30(2), 131-137.

Park, M.-H., Dimitrov, D. M., Patterson, L. G., \& Park, D.-Y. (2017). Early childhood teachers' beliefs about readiness for teaching science, technology, engineering, and mathematics. Journal of Early Childhood Research, 15(3), 275-291. https://doi.org/10.1177/1476718X15614040

Pellegrini, A.D., Bohn-Gettler, C.M., Dupuis, D., Hickey, M., Roseth, C., \& Solberg, D. (2011). An empirical examination of sex differences in scoring preschool children's aggression. Journal of Experimental Child Psychology, 109(2), 232-238. https://doi.org/10.1016/j.jecp.2010.11.003 
Erin E. HAMEL

Riegle-Crumb, C., King, B., Grodsky, E., \& Muller, C. (2012). The more things change, the more they stay the same? Prior achievement fails to explain gender inequality in entry into STEM college majors overtime. American Educational Research Journal, 49(6), 1048-1073. https://doi.org/10.3102/0002831211435229

Robinson-Cimpian, J., Lubienski, S.T., Ganley, C.M., \& Copur-Gencturk, Y. (2014). Teachers' percpetions of students' mathematics proficiency may exacerbate early gender gaps in achievement. Developmental Psychology, 50(4), 1262-1281. https://doi.org/10.1037/a0035073

Rodriguez, M.d.C., Pena, J.V., Fernandez, C.M., \& Vinuela, M.P. (2006). Gender discourse about an ethic of care: Nursery schoolteachers' perspectives. Gender \& Education, 18(2), 183-197. https://doi.org/10.1080/09540250500380547

Şahin-Sak, İ. T., Sak, R., \& Tezel-Şahin, F. (2018). Preschool teachers' views about classroom management models. Early Years, 38(1), 35-52. https://doi.org/10.1080/09575146.2016.1242118

Saldaña, J. (2015). Thinking qualitatively: Methods of mind. SAGE.

Sandberg, A., \& Pramling-Samuelsson, I. (2005). An interview study of gender differences in preschool teachers' attitudes toward children's play. Early Childhood Education Journal, 32(5), 297-305. https://doi.org/10.1007/s10643-005-440-x

Silby, A., \& Watts, M. (2017). Early years science education: A contemporary look. [Editorial]. Early Child Development and Care, 187(2), 179-180. https://doi.org/10.1080/03004430.2016.1237567

Sniegulska, M., \& Pisula, W. (2013). Object exploration in 3- to 7- year old children. Psychological Reports, 113(2), 528-539. https://doi.org/10.2466/10.11.PR0.113x19z1

Staats, C. (2016). Understanding implicit bias: What educators should know. American Educator, 39(4), 29-33. https://files.eric.ed.gov/fulltext/EJ1086492.pdf

Sullivan, J., Moss-Racusin, C., Lopez, M., \& Williams, K. (2018). Backlash against gender stereotype-violating preschool children. PLOSONE, 13(4), 1-24. https://doi.org/10.1371/journal.pone.0195503

Tenenbaum, H.R., \& Leaper, C. (2003). Parent-child conversations about science. Developmental Psychology, 39(1), 34-47. https://doi.org/10.1037/0012-1649.39.1.34

Tomes, R.E. (1995). Teacher presence and child gender influences on children's activity preferences in preschool. Child Study Journal, 25(2), 123-141.

Trawick-Smith, J., Wolff, J., Koschel, M., \& Vallarelli, J. (2015). Effects of toys on the play quality of preschool children: Influence of gender, ethnicity, and socioeconomic status. Early Childhood Education Journal, 43(4), 249-256. https://doi.org/10.1007/s10643$\underline{014-0644-7}$

Tu, T. (2006). Preschool science environment: What is available in a preschool classroom? Early Childhood Education Journal, 33(4), 245251. https://doi.org/10.1007/s10643-005-0049-8

Vitiello, V.E., Booren, L.M., Downer, J.T., \& Williford, A.P. (2012). Variation in children's classroom engagement throughout a day in preschool: Relations to classroom and child factors. Early Childhood Research Quarterly, 27(2), 210-220. https://doi.org/10.1016/j.ecresq.2011.08.005

Wang, X. (2013). Why students choose STEM majors: Motivation, high school learning, and postsecondary context of support. American Educational Research Journal, 50(5), 1081-1121. https://doi.org/10.3102/0002831213488622

Wood, W., \& Eagley, A.H. (2015). Two traditions of research on gender identity. Sex Roles, 73, 461-473. https://doi.org/10.1007/s11199$\underline{015-0480-2}$ 